\title{
Erratum to: Detection of chikungunya virus in saliva and urine
}

Didier Musso ${ }^{1,2^{*}}$, Anita Teissier ${ }^{2}$, Eline Rouault ${ }^{1}$, Sylviane Teururai ${ }^{1}$, Jean-Jacques de Pina ${ }^{1}$ and Tu-Xuan Nhan ${ }^{1}$

\section{Erratum}

Upon publication, it was noticed that in the Acknowledgements section of the original article [1], 'Chikungunya' was mistakenly written as 'Zika'. The acknowledgements have now been corrected below:

We are grateful to the technical team of the medical analysis laboratory of Institut Louis Malardé for their contribution in performing the Chikungunya virus molecular testing.

In addition, the city 'Papeete' was missing from affiliation 2 in the original article. This has now been corrected.

Received: 21 June 2016 Accepted: 21 June 2016

Published online: 04 July 2016

\section{Reference}

1. Musso D, Teissier A, Rouault E, Teururai S, de Pina J-J, Nhan T-X. Detection of chikungunya virus in saliva and urine. Virol J. 2016;13:102.

\footnotetext{
*Correspondence: dmusso@ilm.pf

${ }^{1}$ Laboratoire de biologie médicale, Institut Louis Malardé, PO Box 3098713, Papeete, Tahiti, French Polynesia

2Pôle de recherche et de veille sur les maladies infectieuses émergentes,

Institut Louis Malardé, Papeete, Tahiti, French Polynesia
}

Submit your next manuscript to BioMed Central and we will help you at every step:

- We accept pre-submission inquiries

- Our selector tool helps you to find the most relevant journal

- We provide round the clock customer support

- Convenient online submission

- Thorough peer review

- Inclusion in PubMed and all major indexing services

- Maximum visibility for your research

Submit your manuscript at

www.biomedcentral.com/submit

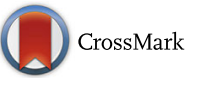
ssMark 